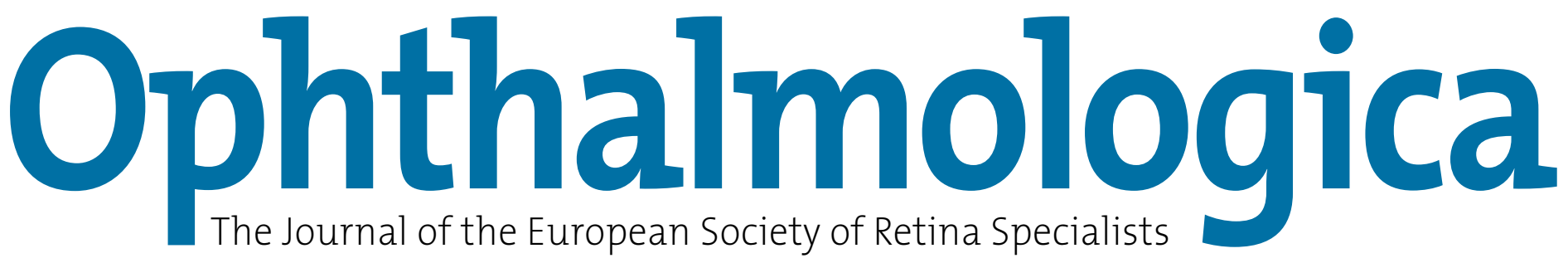

EURETINA

European Society of Retina Specialists

\title{
Progress in Chromovitrectomy
}

\author{
Guest Editor:
}

Carsten H. Meyer, Aarau 


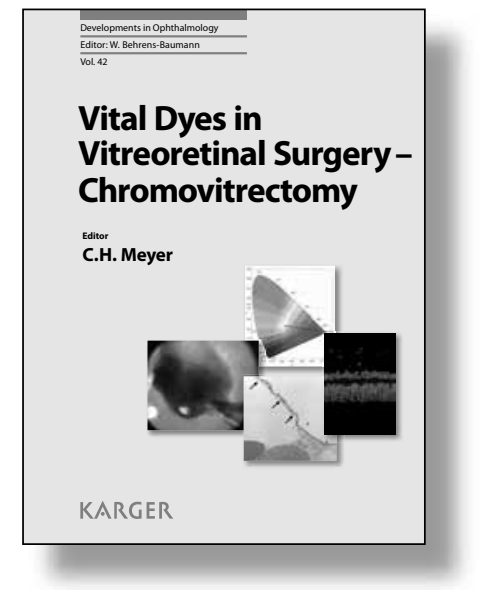

Chromovitrectomy is a novel approach to visualize the vitreous or retinal surface during vitreoretinal surgery. In recent years, the widely used indocyanine green (ICG) has made the surgical maneuver of inner limiting membrane peeling tremendously safer and efficient. Also, numerous dyes have been applied in experimental settings with promising or devastating results.

This volume highlights the major clinical and experimental results of currently used novel vital dyes. The first chapters describe the transparent structure of the vitreous body and summarize historical considerations to visualize its structure by optical coherence tomography, dye injections or autologous cells during surgery and for diagnostic purposes. The following contributions describe the advantages and disadvantages of ICG during vitreoretinal surgery and experimental applications. Alternative approaches by recently approved vital dyes such as trypan blue, patent blue and brilliant blue are evaluated in the subsequent chapters. Finally, the last few chapters give an outlook on novel vital dyes, which are currently under evaluation, as well as alternative enzymatic approaches to remove the vitreous from the retinal surface.

Being a timely update this publication will be indispensable reading for vitreoretinal surgeons and ophthalmic researchers.

\section{Vital Dyes in Vitreoretinal Surgery - Chromovitrectomy}

\author{
Editor \\ Carsten H. Meyer
}

\section{Contents}

List of Contributors

Preface: Meyer, C.H.

A Vitrectomy Is Done, When the Vitreous Is Gone! A Tribute to Prof. Peter Kroll: Meyer, C.H.

To See the Invisible: The Quest of Imaging Vitreous: Sebag, $\boldsymbol{J}$.

Historical Aspects and Evolution of the Application of Vital Dyes in Vitreoretinal Surgery and Chromovitrectomy:

Rodrigues, E.B.; Penha, F.M.; Furlani, B.; Meyer, C.H.; Maia, M.; Farah, M.E.

Three Simple Approaches to Visualize the Transparent Vitreous Cortex during Vitreoretinal Surgery: Schmidt, J.C.; Chofflet, J.; Hörle, S.; Mennel, S.; Meyer, C.H.

Safety Parameters for Indocyanine Green in Vitreoretinal Surgery: Grisanti, s.;

Altvater, A.; Tatar, O.; Peters, S.

Toxicity of Indocyanine Green in Vitreoretinal Surgery: Gandorfer, A.; Haritoglou, C.; Kampik, A.
Biomechanical Changes of the Internal Limiting Membrane after Indocyanine Green Staining: Wollensak, $\mathbf{G}$.

Current Concepts of Trypan Blue in Chromovitrectomy: Farah, M.E.; Maia, M.;

Furlani, B.; Bottós, J.; Meyer, C.H.; Lima, V.; Penha, F.M.; Costa, E.F.; Rodrigues, E.B.

Trityl Dyes Patent Blue $V$ and Brilliant Blue G - Clinical Relevance and in vitro Analysis of the Function of the Outer Blood-Retinal Barrier: Mennel, s. ; Meyer, C.H.; Schmidt, J.; Kaempf, S.; Thumann, $G$.

Brilliant Blue in Vitreoretinal Surgery: Enaida, H.; Ishibashi, $T$.

Vital Staining and Retinal Detachment Surgery: Jackson, T.L.

An Experimental Approach towards Novel Dyes for Intraocular Surgery: Haritoglou, C.; Schüttauf, F.; Gandorfer, A.; Thaler, S. Experimental Evaluation of Microplasmin - An Alternative to Vital Dyes: Gandorfer, $\boldsymbol{A}$.

Author Index

Subject Index

www.karger.com/deoph

\section{Fax: +41 613061234}

S. Karger AG, P.O. Box, CH-4009 Basel (Switzerland) E-Mail orders@karger.ch,www.karger.com

Name/Address:
Chromovitrectomy

Editor: Meyer, C.H. (Bonn)

XII + 164 p., 69 fig., 48 in color, 9 tab., hard cover, 2008

CHF 169. - / EUR 125.50 / USD 169.00

Prices subject to change

EUR price for Germany, USD price for USA only

ISBN 978-3-8055-8551-4

e-ISBN 978-3-8055-8552-1

KARGER
Postage and handling free with prepayment

E Payment:

- Please charge to my credit card

- $\square$ American Express $\square$ Diners $\square$ Eurocard

ᄂ $\square$ MasterCard $\square$ Visa

- Card No.

0

- Exp. date

-

- CVV/CVC

(3 digits in the signature field on the back of VISA and Mastercard)

$\square$ Check enclosed $\quad \square$ Please bill me

Orders may be placed with any bookshop, subscription agency, directly with the publisher or through a Karger distributor.
Date:

$\underline{\text { Signature }}$ 


\section{Ophthalmologica}

\section{International Journal of Ophthalmology}

Founded 1899 as 'Zeitschrift für Augenheilkunde' by H. Kuhnt and J. von Michel Continued by J. Meller (1923-1938), C. Behr (1925-1938), A. Brückner (1938-1959), H.J.M. Weve (1938-1962), H.M. Dekking (1954-1966), J. ten Doesschate (1967-1971), J. François (1959-1979), E.B. Streiff (1954-1979), H. Sautter (1979-1984), W. Straub (1979-1993), Ch. Ohrloff (1994-2009)

\section{Editor}

\section{J. Cunha-Vaz, Coimbra}

\section{Associate Editors}

J. Bainbridge, London

F. Bandello, Milan

R. Belfort Jr., São Paulo

G. Coscas, Créteil

J.C.N. Murta, Coimbra

Y. Ogura, Nagoya

N. Pfeiffer, Mainz

G. Richard, Hamburg

S. Wolf, Bern

\section{Editorial Board}

J.L. Alió, Alicante

D. Balasubramanian, Hyderabad

C. Baudouin, Paris

F. Behar-Cohen, Paris

R. Bernardes, Coimbra

A.J. Bron, Oxford

V. Chong, Oxford

B. Corcóstegui, Barcelona

A. Cruess, Halifax, N.S.

R. Dana, Boston, Mass.

A. Gaudric, Paris

F. Holz, Bonn

Y.N. Hui, Xian

J.B. Jonas, Mannheim

P. Kestelyn, Gent

P.T. Khaw, London

I.K. Kim, Boston, Mass.

T. Kohnen, Frankfurt

C. Lobo, Coimbra

A. Loewenstein, Tel Aviv

B. Lorenz, Giessen
P. Massin, Paris

E. Midena, Padova

A. Negi, Kobe

J.C. Pastor Jimeno, Valladolid

U. Pleyer, Berlin

L. Rossetti, Milan

J.A. Sahel, Paris

U. Schmidt-Erfurth, Vienna

R. Silva, Coimbra

E. Stefánsson, Reykjavík

M.J. Tassignon, Antwerp

K. Tsubota, Tokyo

A. Tufail, London

M. Ulbig, Munich

P. Wiedemann, Leipzig

D. Wong, Liverpool

T.Y. Wong, Singapore

$\mathrm{X}$. Xu, Shanghai

T. Zeyen, Louvain

L. Zografos, Lausanne

E. Zrenner, Tübingen
Printed in Switzerland on acid-free and non-aging paper (ISO 9706) by Reinhardt Druck, Basel
Appears 6-weekly: 2 volumes per yea (8 issues) 


\section{Ophthalmologica}

\section{Submission}

Original papers, reviews and carefully selected case reports written in English are considered for publication. Manuscripts should be submitted online

\section{www.karger.com/oph}

Should you experience any problems with your submission, please contact the Editorial Office at:

\section{oph@karger.com}

\section{Prof. J. Cunha-Vaz}

S. Karger AG

Editorial Office 'Ophthalmologica'

PO Box

$\mathrm{CH}-4009$ Basel (Switzerland)

Fax +4161306 1434

\section{Conditions}

All manuscripts are subject to editorial review. Manuscripts are received with the explicit understanding that they are not under simultaneous consideration by any other publication. A cover letter with the name, address, and telephone and telefax numbers of the corresponding author must accompany each manuscript. This letter must include a statement that affirms that all authors concur with the submission. Submission of an article for publication implies transfer of the copyright from the author to the publisher upon acceptance. Accepted papers become the permanent property of 'Ophthalmologica' and may not be reproduced by any means, in whole or in part, without the written consent of the publisher. It is the author's responsibility to obtain permission to reproduce illustrations, tables, etc. from other publications.

\section{Conflicts of Interest}

Authors are required to disclose any sponsorship or funding arrangements relating to their research and all authors should disclose any possible conflicts of interest. Conflict of interest statements will be published at the end of the article.

\section{Types of Papers}

Editorial

EURETINA - Review

EURETINA - Original Paper

Original Paper

Review

New Technologies in Ophthalmology

Letter to the Editor

Reviews are either invited, or may be submitted for consideration. Invited reviews, if accepted, are not subject to page charges. The recommended length is 6 printed pages (approx. 15 double-spaced manuscript pages).

Mini Reviews should contain an easy-to-read literature overview on a specific topic. Papers are either invited or may be submitted for consideration. Only concise articles of no more than 2 printed pages (approx. 6 doublespaced manuscript pages), including an abstract of max. 200 words and references, will be accepted. Please submit your mini review online.

\section{Letter to the Editor}

Letters are only accepted if they directly concern articles previously published in this journal and clinical subjects related to the matters discussed. The editor reserves the right to submit copies of such letters to the authors of the articles concerned prior to publication in order to permit them to respond in the same issue of the journal. Letters should have a maximum of one printed page (350-420 words, up to 8 references).

\section{Arrangement}

Title page: The first page of each paper should indicate the title, the authors' names, the institute where the work was conducted, and a short title for use as running head.

Full address: The exact postal address of the corresponding author complete with postal code must be given at the bottom of the title page. Please also supply phone and fax numbers, as well as e-mail address.

Key words: Please supply 3-10 key words in English that reflect the content of the paper.

Abstract: Each paper needs an abstract in English of not more than $\mathbf{1 5 0}$ words. The abstract is of utmost importance. It should contain the following information: purpose of the study, procedures, results, conclusions and message of the paper.

\section{Footnotes: Avoid footnotes}

Tables and illustrations: Tables and illustrations (both numbered in Arabic numerals) should be sent in separate files. Tables require a heading and figures a legend, also in a separate file. Due to technical reasons, figures with a screen background should not be submitted. When possible, group several illustrations in one block for reproduction (max. size $180 \times 223 \mathrm{~mm}$ ). Black and white half-tone and color illustrations must have a final resolution of $300 \mathrm{dpi}$ after scaling, line drawings one of $800-1,200 \mathrm{dpi}$.

\section{Color illustrations}

Online edition: Color illustrations are reproduced free of charge. In the print version, the illustrations are reproduced in black and white. Please avoid referring to the colors in the text and figure legends.

Print edition: Up to 6 color illustrations per page can be integrated within the text at CHF 800.- per page.

References: In the text identify references by Arabic numerals [in square brackets]. Material submitted for publication but not yet accepted should be noted as 'unpublished data' and not be included in the reference list. The list of references should include only those publications which are cited in the text. Do not alphabetize; number references in the order in which they are first mentioned in the text. The surnames of the authors followed by initials should be given. There should be no punctuation other than a comma to separate the authors. Preferably, please cite all authors. Abbreviate journal names according to the Index Medicus system. Also see International Committee of Medical Journal Editors: Uniform requirements for manuscripts submitted to biomedical journals (www.icmje.org).

Examples

(a) Papers published in periodicals: Chatel J-M, Bernard $\mathrm{H}$, Orson $\mathrm{FM}$ : Isolation and characterization of two complete Ara h 2 isoforms cDNA. Int Arch Allergy Immunol 2003;131:14-18.

(b) Papers published only with DOI numbers:

Theoharides TC, Boucher W, Spear K: Serum interleukin-6 reflects disease severity and osteoporosis in mastocytosis patients. Int Arch Allergy Immunol DOI: 10.1159/000063858.

(c) Monographs: Matthews DE, Farewell VT: Using and Understanding Medical Statistics, ed 3, revised. Basel, Karger 1996.(d) Edited books: DuBois RN: Cyclooxygenase-2 and colorectal cancer; in Dannenberg AJ, Dubois RN (eds): COX-2. Prog Exp Tum Res. Basel, Karger, 2003, vol 37, pp $124-137$.

Reference Management Software: Use of EndNote is recommended for easy management and formatting of citations and reference lists.

\section{Digital Object Identifier (DOI)}

S. Karger Publishers supports DOIs as unique identifier for articles. A DOI number will be printed on the title page of each article. DOIs can be useful in the future for identifying and citing articles published online without volume or issue information. More information can be found at www.doi.org.

\section{Supplementary Material}

Supplementary material is restricted to additional data that are not necessary for the scientific integrity and conclusions of the paper. Please note that all supplementary files will undergo editorial review and should be submitted together with the original manuscript. The Editors reserve the right to limit the scope and length of the supplementary material. Supplementary material must meet production quality standards for Web publication without the need for any modification or editing. In general, supplementary files should not exceed $10 \mathrm{MB}$ in size. All figures and tables should have titles and legends and all files should be supplied separately and named clearly. Acceptable files and formats are: Word or PDF files, Excel spreadsheets (only if the data cannot be converted properly to a PDF file), and video files (.mov, .avi, .mpeg).

\section{Author's Choice ${ }^{\mathrm{T}}$}

Karger's Author's Choice ${ }^{\mathrm{TM}}$ service broadens the reach of your article and gives all users worldwide free and full access for reading, downloading and printing at www. Karger.com. The option is available for a one-time fee of CHF 3000.-, which is a permissible cost in grant allocation. More information can be found at www.karger.com/ authors_choice.

\section{NIH-Funded Research}

The U.S. National Institutes of Health (NIH) mandates under the NIH Public Access Policy that final, peer-reviewed manuscripts appear in its digital database within 12 months of the official publication date. As a service to authors, Karger submits the final version of your article on your behalf to PubMed Central. For those selecting our premium Author's Choice ${ }^{\mathrm{TM}}$ service, we will send your article immediately upon publishing, accelerating the accessibility of your work without the usual embargo. More details on NIH's Public Access Policy is available at http://publicaccess.nih.gov/policy.htm

\section{Self-Archiving}

Karger permits authors to archive their pre-prints (i.e. prerefereeing) or post-prints (i.e. final draft post-refereeing) on their personal or institution's servers, provided the following conditions are met: Articles may not be used for commercial purposes, must be linked to the publisher's version, and must acknowledge the publisher's copyright. Authors selecting Karger's Author's Choice ${ }^{\mathrm{TM}}$ feature, however, are also permitted to archive the final, published version of their article, which includes copyediting and design improvements as well as citation links.

\section{Page Charges}

There are no page charges for papers of 3 or fewer printed pages (including tables, illustrations and references). Each additional complete or partial page is charged to the author at CHF 325.-. The allotted size of a paper is equal to approx. 8 manuscript pages (including tables, illustrations and references).

\section{Proofs}

Unless indicated otherwise, proofs are sent to the corresponding author and should be returned with the least possible delay. Alterations other than the correction of printer's errors are charged to the author.

\section{Reprints}

Order forms and a price list are sent with the proofs. Orders submitted after the issue is printed are subject to considerably higher prices.

\section{KARGER}

E-Mail karger@karger.com www.karger.com
(C) 2013 S. Karger AG, Basel 


\section{Ophthalmologica}

ISSN Print Edition: 0030-3755

ISSN Online Edition: 1423-0267

Journal Homepage: www.karger.com/oph

Publication Data: 'Ophthalmologica' is published 8 times a year. Volumes 229 and 230, each with 4 issues, appear in 2013.

Copyright: (c) 2013 S. Karger AG, Basel (Switzerland). All rights reserved. No part of this publication may be translated into other languages, reproduced or utilized in any form or by any means, electronic or mechanical, including photocopying, recording, microcopying, or by any information storage and retrieval system, without permission in writing from the publisher or, in the case of photocopying, direct payment of a specified fee to the Copyright Clearance Center.

Disclaimer: The statements, opinions and data contained in this publication are solely those of the individual authors and contributors and not of the publisher and the editor(s). The appearance of advertisements in the journal is not a warranty, endorsement, or approval of the products or services advertised or of their effectiveness, quality or safety. The publisher and the editor(s) disclaim responsibility for any injury to persons or property resulting from any ideas, methods, instructions or products referred to in the content or advertisements.
Subscription Rates: Subscriptions run for a full calendar year. Prices are given per year. Personal subscription:

Print or Online

CHF 1018.-

EUR 820.-

USD 1008.00

Print+Online combined CHF 1114.-

EUR 898.-

postage and handling (added to print and print+online)

CHF 57.60 Europe, CHF 83.20 Overseas

EUR 44.80

USD 76.80

Institutional subscription:

Print or Online

Print+Online combined

CHF 2034.

EUR 1640.-

CHF 2238.-

postage and handling (added to print and print+online)

CHF 72.- Europe, CHF 104.- Overseas

EUR 56.-

USD 96.00

Airmail surcharge: CHF 70.- / USD 66.00

Discount subscription prices:

- Association for Research and Vision in

Ophthalmology (ARVO)

- EVER

- EURETINA

- and other related societies
Back Volumes and Single Issues: Information on availability and prices of single print issues and print or electronic back volumes can be obtained from Customer Service atservice@karger.com.

Bibliographic Indices: This journal is regularly listed in bibliographic services, including Current Contents ${ }^{\circledR}$ and PubMed/MEDLINE.

Photocopying: This journal has been registered with the Copyright Clearance Center (CCC), as indicated by the code appearing on the first page of each article. For readers in the US, this code signals consent for copying of articles for personal or internal use, or for the personal or internal use of specific clients, provided that the stated fee is paid per copy directly to

Copyright Clearance Center Inc.

222 Rosewood Drive

Danvers, MA 01923 (USA)

A copy of the first page of the article must accompany payment. Consent does not extend to copying for general distribution, for promotion, for creating new works, or for resale. In these cases, specific written permission must be obtained from the copyright owner,

S. Karger AG, P.O. Box

CH-4009 Basel (Switzerland).

\begin{tabular}{|c|c|c|}
\hline \multirow{3}{*}{$\begin{array}{l}\text { Subscription Orders: } \\
\text { Orders can be placed at agencies, } \\
\text { bookstores, directly with the Publisher }\end{array}$} & or further Karger offices & USA \\
\hline & or representatives: & $\begin{array}{l}\text { S. Karger Publishers, Inc. } \\
26 \text { West Avon Road }\end{array}$ \\
\hline & Germany & P.O. Box 529 \\
\hline S. Karger AG & S. Karger GmbH & Unionville, CT 06085 \\
\hline Medical and Scientific Publishers & Postfach & USA \\
\hline Allschwilerstrasse 10 & 79095 Freiburg & Toll free: +1 8008285479 \\
\hline CH-4009 Basel & Deutschland & $\mathrm{t}: \quad+18606757834$ \\
\hline Switzerland & $\begin{array}{l}\text { (Hausadresse: Wilhelmstrasse 20A, } \\
79098 \text { Freiburg) }\end{array}$ & $\begin{array}{l}\mathrm{f}:+18606757302 \\
\text { e: karger@snet.net }\end{array}$ \\
\hline t: +41613061111 & $\mathrm{t}: \quad+49761452070$ & \\
\hline f: +41613061234 & $\mathrm{f}: \quad+497614520714$ & France \\
\hline e: karger@karger.com & e: information@karger.de & Librairie Médi-Sciences Sarl \\
\hline w: www.karger.com & w: www.karger.de & $\begin{array}{l}\text { 36, bd de Latour-Maubourg } \\
75007 \text { Paris }\end{array}$ \\
\hline (for courier services only: & Japan & France \\
\hline Allschwilerstrasse 10 & Karger Japan, Inc. & $\mathrm{t}: \quad+33(0) 145514258$ \\
\hline CH-4055 Basel) & Shiba Daimon Asahi Bldg. 2F & $\mathrm{f}: \quad+33(0) 145560780$ \\
\hline & 1-2-23 Shiba Daimon & e: librairie@medi-sciences.fr \\
\hline & Minato-ku & w: www.medi-sciences.fr \\
\hline & Tokyo 105-0012 & \\
\hline & Japan & \\
\hline & t: +81364356242 & \\
\hline & f: +81364356244 & \\
\hline & $\begin{array}{l}\text { e: publisher@karger.jp } \\
\text { w: www.karger.jp }\end{array}$ & \\
\hline
\end{tabular}

Change of Address:

Both old and new address should be sent

to the subscription source.

\section{KARGER}

E-Mail karger@karger.com www.karger.com
(C) 2013 S. Karger AG, Basel

The Journal Home Page is available at: www.karger.com/oph
South East Asia, China and Taiwan Karger Regional Office (Malaysia) CEO Suite Kuala Lumpur Quill 7, 27th Floor

Jalan Stesen Sentral 5

KL Sentral

Kuala Lumpur 50470

Malaysia

$\mathrm{t}:+60327766803$

f. +60327766999

e: service@karger.cn; r.chew@karger.cn

Karger China

10th Floor, Twin Towers (East)

B12 Jianguomenwai Avenue

Beijing 100022

China

t: +861051235033

$\mathrm{f}:$ +86 1051235122

e: service@karger.cn; r.chew@karger.cn

w: www.karger.cn

India, Bangladesh, Sri Lanka

Medscience India

Plot No. 17, Yusuf Sarai Market

B.L. Glass Building, 2nd Floor

Sri Aurobindo Marg

New Delhi 110016

India

t: +911146029633

f: +911146029634

c: +919891052128

e: medsci.india@gmail.com 


\title{
A complete overview of treatment strategies and new therapeutic options
}

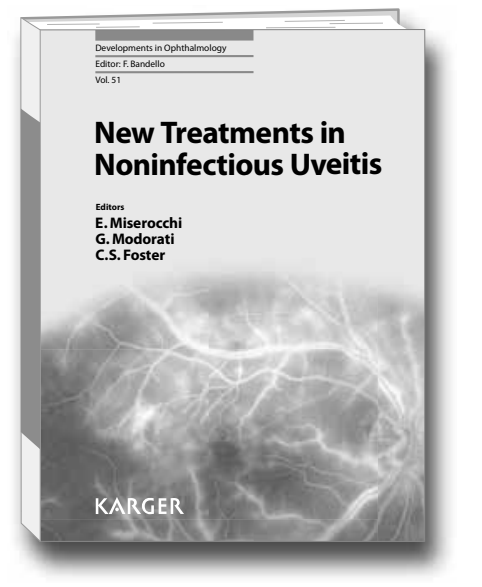

\section{New Treatments in Noninfectious Uveitis}

\author{
Editors \\ Elisabetta Miserocchi \\ Giulio Modorati \\ C. Stephen Foster
}

Uveitis is a potentially blinding inflammatory disease that presents one of the most serious and complicated therapeutic challenges in the field of ophthalmology. During the last decade, the therapeutic armamentarium of the uveitis specialist has enormously expanded. Novel biologic agents and intraocular therapy are becoming a valuable alternative treatment to control ocular inflammatory diseases and inflammatory macular edema - the most important cause of visual loss in patients with uveitis.

This publication is designed to bring together the principles of therapy of patients with noninfectious uveitis and the most recent therapeutic options available. General ophthalmologists, uveitis specialists as well as residents will find it a useful update on the latest innovative treatment options for patients with noninfectious uveitis.

\section{Contents}

Preface: Miserocchi, E.; Modorati, G.; Foster, C.S. The Philosophy of Treatment of Uveitis:

Past, Present and Future: Kruh, J.; Foster, C.S.

The Gold Standard of Noninfectious Uveitis:

Corticosteroids: Lehoang, $\boldsymbol{P}$.

Corticosteroid-Sparing Agents: Conventional

Systemic Immunosuppressants: Kruh, J.;

Foster, C.S.

Corticosteroid-Sparing Agents:

New Treatment Options: Tomkins-Netzer, O.; Taylor, S.R.J.; Lightman, S.

Mycophenolate Mofetil Use in the Treatment of Noninfectious Uveitis: Klisovic, D.D.

Anti-Tumor Necrosis Factor- $\alpha$ Agents in

Noninfectious Uveitis: Gueudry, J.;

LeHoang, P.; Bodaghi, B.

New Biologic Drugs: Anti-Interleukin

Therapy: Tappeiner, C.; Möller, B.; Hennig, M.; Heiligenhaus, $A$.
Interferon- $\alpha$ Therapy in Noninfectious Uveitis: Deuter, C.; Stübiger, N.; Zierhut, $\boldsymbol{M}$.

Rituximab for Noninfectious Uveitis: Miserocchi, E.; Modorati, G.

Intravitreal Injection Therapy in the Treatment of Noninfectious Uveitis: Modorati, G.; Miserocchi, E.

Corticosteroid Intravitreal Implants: de Smet, M.D.

New Treatment Options for Noninfectious Uveitis: Gomes Bittencourt, M.; Sepah, Y.J.; Do, D.V.; Agbedia, O.; Akhtar, A.; Liu, H.; Akhlaq, A.; Annam, R.; Ibrahim, M.; Nguyen, Q.D.

Subject Index
Developments in Ophthalmology, Vol. 51 Series Editor: Bandello, F. (Milan)

ISSN 0250-3751 / e-ISSN 1662-2790

New Treatments in Noninfectious Uveitis Editors: Miserocchi, E.; Modorati, G. (Milan); Foster, C.S. (Boston, Mass.)

XII + 166 p., 14 fig., 8 in color, 24 tab., hard cover, 2012 CHF 159.- / EUR 133.- / USD 187.00

Prices subject to change

EUR price for Germany, USD price for USA only

ISBN 978-3-8055-9986-3

e-ISBN 978-3-8055-9987-0

\section{Please send: __ copy/ies}

$\boldsymbol{\varepsilon}$

Payment:

- Please charge to my credit card

- $\square$ American Express $\square$ Diners

ᄂ $\square$ MasterCard $\square$ Visa

- Card No

o

ర Exp. date:

-

- $\mathrm{CVV} / \mathrm{CVC}$

( 3 digits in the signature field on the back of Visa and MasterCard)

$\square$ Check enclosed $\square$ Please bill me

Orders may be placed with any bookshop, subscription agency, directly with the publisher or through a Karger distributor.
Fax: +41 613061234

S. Karger AG, P.O. Box, $\mathrm{CH}-4009$ Basel (Switzerland) E-Mail orders@karger.ch, www.karger.com

Name/Address: 


\section{Contents}

See the journal website for contents

KARGER Basel $\bullet$ Freiburg $\cdot$ Paris $\bullet$ London $\bullet$ New York $\cdot$ New Delhi $•$ Bangkok Beijing $\cdot$ Tokyo $\cdot$ Kuala Lumpur $\cdot$ Singapore $\bullet$ Sydney 


\section{A comprehensive and in-depth review \\ by leading experts}

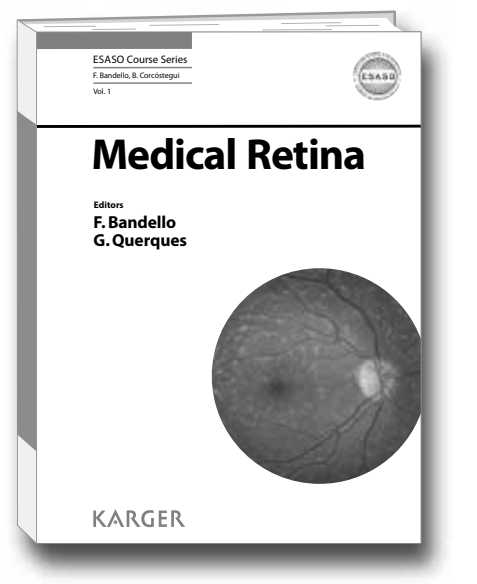

In the new book series ESASO Course Series, the essentials of the courses of the European School for Advanced Studies in Ophthalmology (ESASO) are made available to interested ophthalmologists, optometrists, technicians and residents all over the world.

In this first volume, the seminars on medical retina presented by renowned experts during ESASO's activities are collected. The authors have incorporated their personal experience and full teaching acumen in their respective chapters. The topics range from molecular biology, to state-of-the-art diagnostic techniques and the newest medical treatment options.

This book provides the ophthalmologist with the most recent data and evidence-based medicine on medical retina, and includes multiple areas still under debate. Because of its highly specific and updated information, focusing on the pathogenesis and management of retinal diseases, this publication is a must to all retina specialists.

\section{Medical Retina}

Editors

Francesco Bandello

Giuseppe Querques

\section{Contents}

Foreword: Guarnaccia, $\mathbf{G}$.

Preface: Bandello, F.; Querques, G.

Embryology and Anatomy of the Baby's Posterior Segment: Trese, M.T.

Blood-Retinal Barrier and Its Relevance in Retinal Disease: Cunha-Vaz, J.

Imaging the Retina: Cunha-Vaz, J.

Do We Need Fluorescein Angiography?

Noninvasive Imaging of the Eye Fundus: Cunha-Vaz, J.

Treatment of Retinopathy of Prematurity: Capone, A., Jr.

Retinal Development and the Pathogenesis of Retinopathy of Prematurity: Capone, $\boldsymbol{A}$., Jr.

Retinopathy of Prematurity: Cases and Diagnosis: Trese, M.T.

Retinopathy of Prematurity: Laser Treatment and Intravitreal Injections: Trese, M.T.

Vitreoretinal Surgery for Retinopathy of Prematurity: Trese, M.T.

Proliferative Vitreoretinopathy: Mateo, $\boldsymbol{C}$.; Burés-Jelstrup, $A$.

Inherited Retinal Pigmentary Degenerations and Inherited Macular Dystrophies: Navarro, $\boldsymbol{R}_{\mathbf{~}}$ Burés-Jelstrup, $\boldsymbol{A}$.

Pediatric Vitreoretinal Diseases Not Associated with Prematurity: Capone, A., Jr.
Other Vitreoretinal Pathologies in Infants: Trese, M.T.

Vascular Anomalies of the Fundus Oculi: Diagnosis and Treatment: Lanzetta, P.; Veritti, $\boldsymbol{D}$.

Retinal Artery Occlusion: Bandello, F.; Battaglia Parodi, $\boldsymbol{M}$.

Retinal Artery Occlusion and Acute Choroidal Ischemia: Gaudric, $\boldsymbol{A}$.

Ocular Ischemic Syndrome: Bandello, F.; Battaglia Parodi, $M$.

Diabetic Retinopathy: Williams, G.A.

Diabetic Macular Edema: Williams, G.A.

Proliferative Diabetic Retinopathy: Surgical Treatment and Handling of Intraoperative and Postoperative Complications: Garcia-Arumi, J.; Boixadera, A.; Martinez-Castillo, V.; Zapata, M.A.

Retinal Venous Occlusions: Diagnosis and Choice of Treatments: Garcia-Arumi, J.; Badal, J.; Zapata, M.; Boixadera, A.; Martinez Castillo, V.

Vitrectomy for Macular Hole: Gaudric, $\boldsymbol{A}$.; Tadayoni, $\boldsymbol{R}$.

Pathogenesis of Age-Related Macular Degeneration: Zarbin, M.A.

Treatment of Dry Age-Related Macular Degeneration: Zarbin, M.A.; Rosenfeld, P.J. Myopic Macula: Mateo, C.; Burés-Jelstrup, $\boldsymbol{A}$. Fine-Needle Aspiration Biopsy in Intraocular Tumors: Pelayes, D.E.

Subject Index

ww w.karger.com/esaso

Subject Index

\begin{tabular}{|c|c|c|}
\hline $\begin{array}{l}\text { ESASO Course Series, Vol. } 1 \\
\text { Series Editors: Bandello, F. (Milan); Corcóstegui, B. } \\
\text { (Barcelona) }\end{array}$ & $\longrightarrow$ & $\begin{array}{l}\text { Please send: } \_ \text {copy/ies } \\
\text { Postage and handling free with prepayment }\end{array}$ \\
\hline ISSN 1664-882X / e-ISSN 1664-8838 & $\boldsymbol{\varepsilon}$ & Payment: \\
\hline Medical Retina & & Please charge to my credit card \\
\hline Editors: Bandello, F. (Milan); Querques, G. (Paris) & $\circ$ & $\square$ American Express $\square$ Diners \\
\hline $\begin{array}{l}X+160 \text { p., } 88 \text { fig., } 68 \text { in color, } 10 \text { tab., soft cover, } 2012 \\
\text { CHF 98.- / EUR 82.- / USD } 115.00\end{array}$ & レ & $\square$ MasterCard \\
\hline $\begin{array}{l}\text { Prices subject to change } \\
\text { EUR price for Germany, USD price for USA only }\end{array}$ & 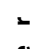 & Card No.: \\
\hline ISBN 978-3-8055-9990-0 & & \\
\hline e-ISBN 978-3-8055-9991-7 & ర & Exp. date: \\
\hline & 0 & CVV/CVC \\
\hline 回源的-口 & & ( 3 digits in the signature field on the back of Visa and MasterCard) \\
\hline 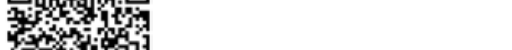 & & $\square$ Check enclosed $\quad \square$ Please bill me \\
\hline 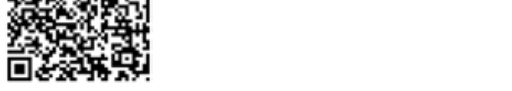 & & $\begin{array}{l}\text { Orders may be placed with any bookshop, subscription } \\
\text { agency, directly with the publisher or through a Karger } \\
\text { distributor. }\end{array}$ \\
\hline
\end{tabular}

Fax: +41613061234

S. Karger AG, P.O. Box, CH-4009 Basel (Switzerland)

E-Mail orders@karger.ch,www.karger.com

Name/Address:

Date: 


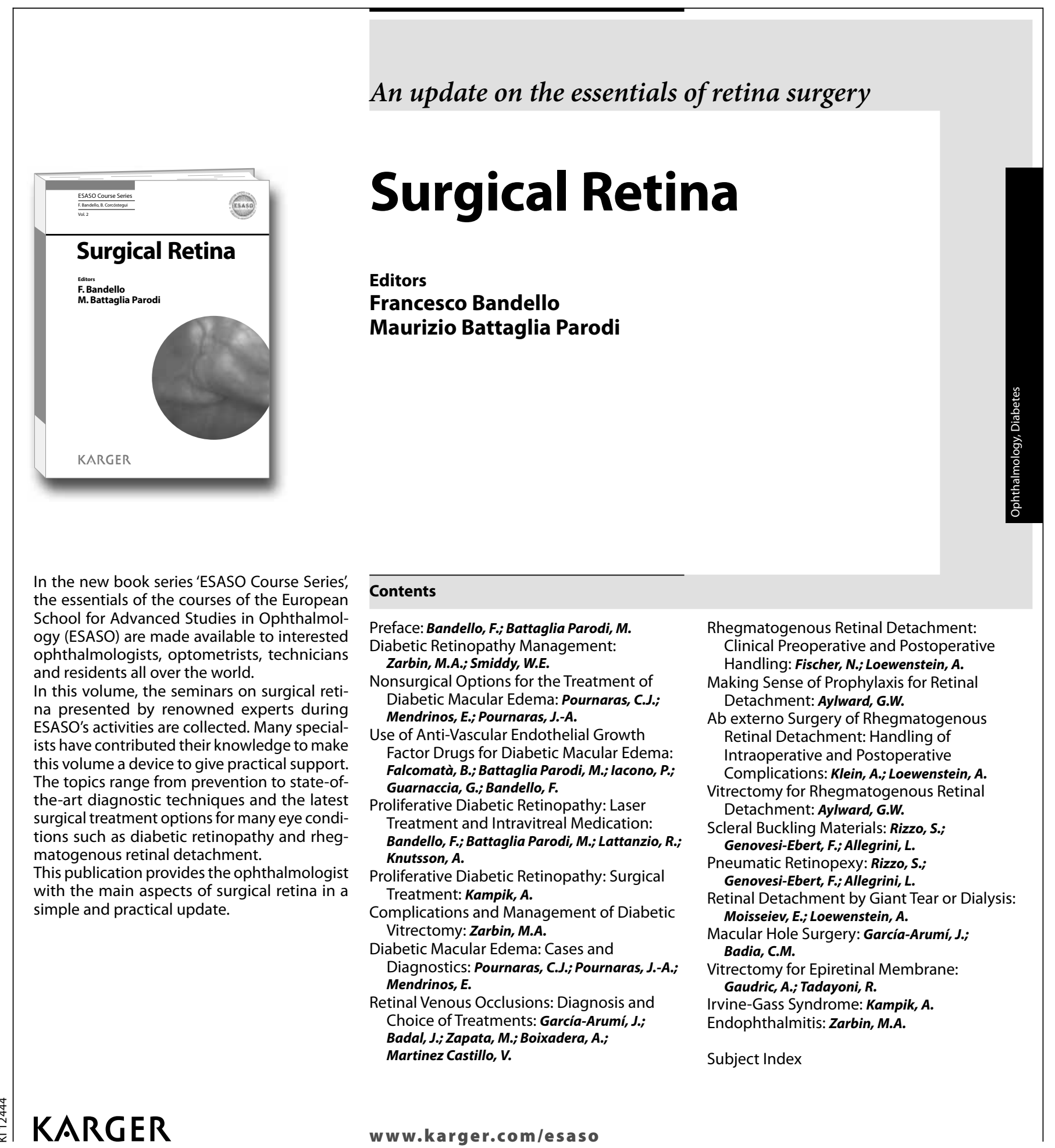

In the new book series 'ESASO Course Series', the courses of the European School for Advanced Studies in Ophthalmol(ESASO) are made available to interested ophthalmologists, optometrists, technicians .

na presented by renowned experts during ESASO's activities are collected. Many specialsurgical treatment options for many eye condisuch as diabetic retinopathy and rhegThis publication provides the ophthalmologist with the main aspects of surgical retina in a simple and practical update.

ESASO Course Series, Vol. 2 Series Editors: Bandello, F. (Milan); Corcóstegui, B. (Barcelona) ISSN 1664-882X e-ISSN 1664-8838

\section{Surgical Retina}

ESASO modules 2009 and 2010: Selected contributions Editors: Bandello, F.; Battaglia Parodi, M. (Milan)

$X+178$ p., 89 fig., 56 in color, 23 tab., hard cover, 2012 CHF 98.- / EUR 82.- / USD 115.00

Prices subject to change

EUR price for Germany, USD price for USA only ISBN 978-3-318-02158-5 e-ISBN 978-3-318-02159-2

\section{$\rightarrow$ Please send:}

Payment:

Please charge to my credit card

$\square$ American Express $\square$ Diners

$\square$ MasterCard

- Card No.:

๑

ర Exp. date:

- CVV/CVC

( 3 digits in the signature field on the back of Visa and MasterCard)

$\square$ Check enclosed $\square$ Please bill me

Orders may be placed with any bookshop, subscription agency, directly with the publisher or through a Karger distributor.
Fax: +41613061234

S. Karger AG, P.O. Box, CH-4009 Basel (Switzerland) E-Mail orders@karger.ch,www.karger.com

Name/Address:

Date: 


\section{Patient-oriented scientific reports covering all aspects of ophthalmology}

Ophthalmologica

The Journal of the European Society of Retina Specialists

\section{Editor}

J. Cunha-Vaz, Coimbra
Associate Editors

J. Bainbridge, London

F. Bandello, Milan

F. Behar-Cohen, Paris

R. Belfort Jr., São Paulo

G. Coscas, Créteil

J.C.N. Murta, Coimbra

Y. Ogura, Nagoya

R.J. Olson, Salt Lake City

N. Pfeiffer, Mainz

G. Richard, Hamburg

S. Wolf, Bern
An Official Journal of the

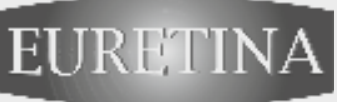

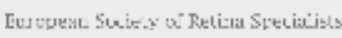

Impact Factor: 1.424

Ophthalmologica
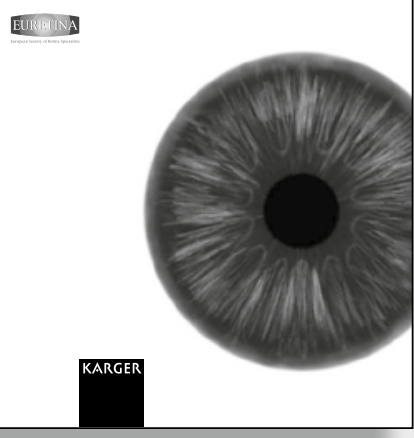

More information at

\section{www.karger.com/oph}

- Pay-per-View and Subscriber Access to Full Text

- Full Table of Contents

- Full Editorial Board

- Free Abstracts and Selected Articles

- Online Sample Issue

- Submission/Guidelines for Authors

- Subscription Details

- Free Alert Service

- Online Library Recommendation

\section{Selected contributions}

- Management of Retinal Vein Occlusion - Consensus Document: Coscas, G. (Créteil); Loewenstein, A. (Tel Aviv); Augustin, A. (Karlsruhe); Bandello, F.; Battaglia Parodi, M. (Milan); Lanzetta, P. (Udine); Monés, J. (Barcelona); de Smet, M. (Amsterdam); Soubrane, G. (Créteil); Staurenghi, G. (Milan)

- Müller Glial Cells in Retinal Disease: Bringmann, A.; Wiedemann, P. (Leipzig)

- Oxygen Sensing in Retinal Health and Disease: Lange, C.A.K. (London/Freiburg); Bainbridge, J.W.B. (London)

- Noninvasive Evaluation of Retinal Leakage Using Optical Coherence Tomography: Bernardes, R.; Santos, T.; Serranho, P.; Lobo, C.; Cunha-Vaz, J. (Coimbra)

- Imaging Geographic Atrophy in Age-Related Macular Degeneration: Göbel, A.P.; Fleckenstein, M.; Schmitz-Valckenberg, S.; Brinkmann, C.K.; Holz, F.G. (Bonn)

- Outcomes of Epiretinal Membrane Removal in Eyes with and without Concurrent Vision-Limiting Ocular Disease: Moisseiev, E.; Davidovitch, Z.; Loewenstein, A.; Barak, A. (Tel Aviv)

- Outcomes and Complications of 25-Gauge Transconjunctival Sutureless Vitrectomy for Proliferative Diabetic Retinopathy: Ozone, D.; Hirano, Y.; Veda, J.; Yasukawa, T.; Yoshida, M.; Ogura, Y. (Nagoya)

- Improved Automated Screening of Diabetic Retinopathy: Oliveira, C.M.; Cristóvão, L.M.; Ribeiro, M.L.; Faria Abreu, J.R. (Coimbra)
Published since 1899, Ophthalmologica has become a frequently cited guide to international work in clinical and experimental ophthalmology. It contains a selection of patient-oriented contributions covering the etiology of eye diseases, diagnostic techniques, and advances in medical and surgical treatment, with special emphasis on retinal diseases. In addition to original papers, Ophthalmologica features regularly timely reviews in an effort to keep the reader well informed and updated. The large international circulation of this journal reflects its importance.

Ophthalmologica

2013: Volume 229, 230

4 issues per volume

Language: English

ISSN 0030-3755 (print)

ISSN 1423-0267 (online) 


\section{Ophthalmologica}

\section{Editorial}

3 Chromovitrectomy and the Vitreoretinal Interface Schumann, R.G.; Haritoglou, C. (Munich)

11 Material Properties of the Internal Limiting Membrane and Their Significance in Chromovitrectomy Henrich, P.B.; Monnier, C.A.; Loparic, M.; Cattin, P.C. (Basel)

21 The Retinal Biocompatibility of Dyes in the ex vivo Model of the Isolated Superfused Vertebrate Retina Lüke, M.; Grisanti, S.; Lüke, J. (Lübeck)

27 Improved Brilliant Blue G Staining of the Internal Limiting Membrane with Sharp Cut Filters of a Novel Viewing Filter System

Enaida, H.; Yoshida, S.; Nakao, S.; Ikeda, Y. (Fukuoka); Hachisuka, Y.; Oshima, Y. (Tokyo); Kadonosono, K. (Yokohama); Ueno, A.; Ishibashi, T. (Fukuoka)

33 Effect of Novel Vital Dyes on Outer Blood-Retina Barrier Function in Cultured Human Retinal Pigment Epithelium Liu, Z. (Bonn); Meyer, C.H. (Bonn/Olten); Stanzel, B.V. (Bonn)

41 Effect of Vital Dyes on Retinal Pigmented Epithelial Cell Viability and Apoptosis: Implications for Chromovitrectomy Penha, F.M. (São Paulo); Pons, M. (Miami, Fla.); de Paula Fiod Costa, E.; Rodrigues, E.B.; Maia, M. (São Paulo); Marin-Castaño, M.E. (Miami, Fla.); Farah, M.E. (São Paulo)
51 Dyes for Eyes ${ }^{\mathrm{TM}}$ : Hydrodynamics, Biocompatibility and Efficacy of 'Heavy' (Dual) Dyes for Chromovitrectomy Mohr, A. (Bremen); Bruinsma, M.; Oellerich, S. (Rotterdam); Frank, H. (Delft); Gabel, D. (Bremen); Melles, G.R.J. (Rotterdam)

59 Biochemical Analysis and Decomposition Products of Indocyanine Green in Relation to Solvents, Dye Concentrations and Laser Exposure

Penha, F.M.; Rodrigues, E.B.; Maia, M. (São Paulo); Meyer, C.H. (Bonn); de Paula Fiod Costa, E.; Dib, E.; Bechara, E.; Lourenço, A.; Lima Filho, A.A.S.; Freymüller, E.H.; Farah, M.E. (São Paulo)

68 Staining Properties of Brilliant Blue Depending on Different Incubation Times and Solvents in Humans Rodrigues, E.B.; Maia, M.; Penha, F.M.; Dib, E.; Melo, G.B.; Maia, A.; Farah, M.E. (São Paulo)

73 A Trichrome RGB Endoillumination Prototype System: A Novel Application for Chromovitrectomy Saxena, S.; Meyer, C.H. (Aarau)

77 Author Index/Subject Index 